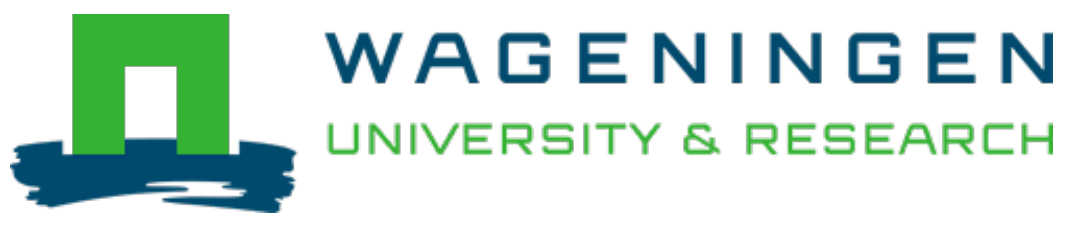

\title{
Towards a New Generation of Trait-Flexible Vegetation Models
}

Trends in Ecology and Evolution

Berzaghi, Fabio; Wright, Ian J.; Kramer, Koen; Oddou-Muratorio, Sylvie; Bohn, Friedrich J. et al https://doi.org/10.1016/j.tree.2019.11.006

This publication is made publicly available in the institutional repository of Wageningen University and Research, under the terms of article $25 \mathrm{fa}$ of the Dutch Copyright Act, also known as the Amendment Taverne. This has been done with explicit consent by the author.

Article $25 \mathrm{fa}$ states that the author of a short scientific work funded either wholly or partially by Dutch public funds is entitled to make that work publicly available for no consideration following a reasonable period of time after the work was first published, provided that clear reference is made to the source of the first publication of the work.

This publication is distributed under The Association of Universities in the Netherlands (VSNU) 'Article $25 \mathrm{fa}$ implementation' project. In this project research outputs of researchers employed by Dutch Universities that comply with the legal requirements of Article $25 \mathrm{fa}$ of the Dutch Copyright Act are distributed online and free of cost or other barriers in institutional repositories. Research outputs are distributed six months after their first online publication in the original published version and with proper attribution to the source of the original publication.

You are permitted to download and use the publication for personal purposes. All rights remain with the author(s) and / or copyright owner(s) of this work. Any use of the publication or parts of it other than authorised under article $25 \mathrm{fa}$ of the Dutch Copyright act is prohibited. Wageningen University \& Research and the author(s) of this publication shall not be held responsible or liable for any damages resulting from your (re)use of this publication.

For questions regarding the public availability of this publication please contact openscience.library@,wur.nl 


\title{
Towards a New Generation of Trait-Flexible Vegetation Models
}

\author{
Fabio Berzaghi, ${ }^{1,2,3, \star}$ lan J. Wright, ${ }^{2}$ Koen Kramer, ${ }^{4}$ Sylvie Oddou-Muratorio, ${ }^{5}$ Friedrich J. Bohn, ${ }^{6,7}$ \\ Christopher P.O. Reyer, ${ }^{8}$ Santiago Sabaté,,${ }^{9,10}$ Tanja G.M. Sanders, ${ }^{11}$ and Florian Hartig ${ }^{12}$
}

\begin{abstract}
Plant trait variability, emerging from eco-evolutionary dynamics that range from alleles to macroecological scales, is one of the most elusive, but possibly most consequential, aspects of biodiversity. Plasticity, epigenetics, and genetic diversity are major determinants of how plants will respond to climate change, yet these processes are rarely represented in current vegetation models. Here, we provide an overview of the challenges associated with understanding the causes and consequences of plant trait variability, and review current developments to include plasticity and evolutionary mechanisms in vegetation models. We also present a roadmap of research priorities to develop a next generation of vegetation models with flexible traits. Including trait variability in vegetation models is necessary to better represent biosphere responses to global change.
\end{abstract}

\section{A Short Review of Trait Variability and Its Consequences for Ecosystems}

Plants are the main primary producers in the terrestrial biosphere and have major impacts on global biogeochemical cycles and climate (e.g., [1-3]). Plant ecosystems also maintain an astonishing amount of biological diversity and provide a multitude of ecosystem services (e.g., [4]). They do so, at each location, through a mix of growth forms and physiological functions that is known as phenotypic or trait variability (see Glossary) [5].

The study of trait variability has a long tradition in ecology. After all, selection on heritable intraspecific trait variability was the key idea for Darwin's theory of evolution. During the 1970 and 1980s, the emerging field of comparative ecology emphasized plant ecological strategies and analyses of interspecific trait variability and trade-offs between species [6-8]. Energetic organization of trait data during the past 20 years [9-14] has enabled broad-scale quantification of key traits and trade-offs across space and time, and across taxonomic and functional groups $[15,16]$. A fundamental insight is that certain combinations of traits jointly characterize plant life-histories and their ecological strategies $[17,18]$. Increasingly, the focus is shifting to the effects of both intraspecific variability [19-21] and rapid evolution [22] in the context of species and ecosystem adaptation to climate change.

Observed within- and between-species variability in plant functional traits can result from plastic responses to biotic and abiotic conditions, and from heritable genetic or epigenetic differences (e.g., [20,23-26], Table 1 and Figure 1). Evidence for within-species variability from common garden experiments/provenance trials [27-30], and observations of rapid evolution [30-32] demonstrate that intraspecific phenotypic differences are often heritable and adaptive. This suggests that traits can evolve on ecological timescales and that the concept of a species as a functionally static unit is an approximation at best.

A challenge for understanding the consequences of trait variability is that we seldom know whether measured trait differences arise from standing diversity, plasticity, or both (Table 1). There is hope that population genomics and next-generation sequencing [33] could establish genotype-to-phenotype maps [34] and make it easier to decipher the genetic and plastic components of observed patterns of variation. Currently, however, most data only document existing patterns of trait variability, with no guarantee that this variability will persist over time (e.g., under changing climates).

Another key challenge is understanding the consequences of trait variability. Trait variability is often assumed to be critical for competition, fitness, adaptation, and resilience in plant communities,
Highlights

Dynamic vegetation models are the main tools to assess climate change effects on terrestrial vegetation. Therefore, a realistic representation of biological processes in these models is of utmost importance. Intraspecific trait variability is ubiquitous in plants and, thus, the underlying processes causing it should be represented. Yet, trait variability is only used to a limited extent in current vegetation models.

Empirical and theoretical studies make clear that intraspecific trait variability underpins evolutionary and plastic plant responses to environmental changes. We review progress towards 'next-generation' models that include evolutionary and plastic processes, including those explicitly representing genetic mechanisms.

Modeling paradigms where plant diversity emerges mechanistically are necessary to understand both functional trade-offs (e.g., leaf and wood economics spectra) and spatial patterns of genetic and phenotypic variability as exposed by genomic and ecological data.

1Laboratory for Sciences of Climate and Environment (LSCE) - UMR CEA/CNRS/UVSQ, Gif-sur-Yvette 91191 France

2Department of Biological Sciences, Macquarie University, Sydney, NSW 2022, Australia

${ }^{3}$ Dipartimento per la Innovazione nei sistemi Biologici, Agroalimentari e Forestali, University of Tuscia, Viterbo 01100, Italy

${ }^{4}$ Wageningen University and Research, Droevendaalse steeg 4, 6700AA Wageningen, The Netherlands

5URFM "Ecology of Mediterranean Forests", INRAE, 84000 Avignon, France 


\section{Trends in Ecology \& Evolution}

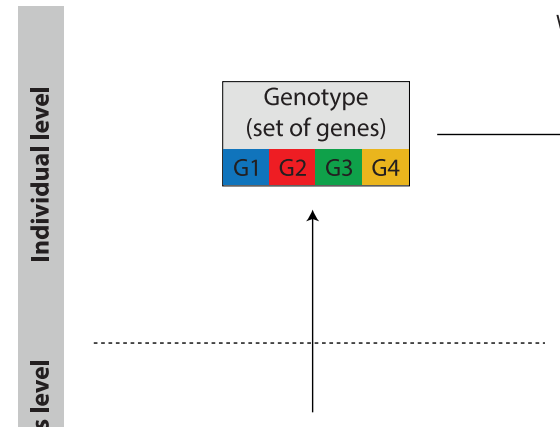

Within-lifetime processes
Standing diversity of genotypes (set of genes)

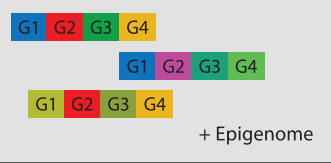

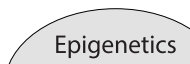

Gene expression Plasticity

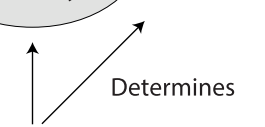
environment

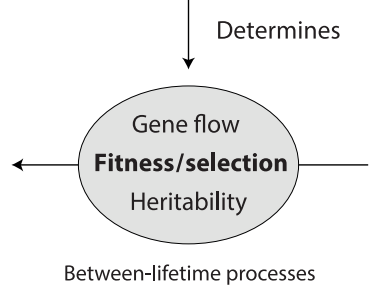

Between-lifetime processes
Biotic and abiotic

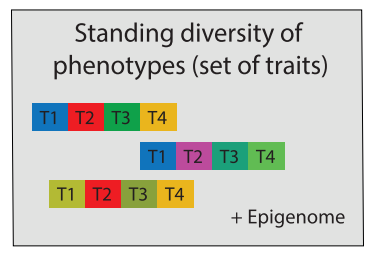

Trends in Ecology \& Evolution
Figure 1. Conceptual Figure of Trait Variability.

Rectangles represent states (genotype or phenotype) and ovals represent the processes driving variability. The top half represents individual-level processes determining trait variability within a lifetime. The bottom half represents community- or population-level processes that influence variability between generations. Dashed arrows represent how genetic and plasticity can trigger changes in phenotype within a lifetime of an individual.

particularly during rapid climatic change $[35,36]$ because, for example, trait variability likely increases evolvability, and buffers species and ecosystems against environmental fluctuations $[20,23,26]$. However, theoretical models show that trait variability is not always beneficial [37] and empirical studies often fail to demonstrate the expected links to fitness [38]. Thus, the consequences of trait variability appear more complex and context dependent than commonly assumed. If true, an obvious, and possibly the only, route forward is to explore these questions with models that describe traits in a more quantitative and mechanistic way.

\section{Modeling the Consequences and Evolution of Plant Trait Variability: The Crucial Role of Vegetation Models}

Detailed mechanistic models already exist that describe communities of plant species in terms of their underlying biogeochemical and ecological processes [dynamic vegetation models (DVM); Box 1; [39-41]]. These models have been instrumental for understanding global biome distributions and for creating dynamic projections of plant ecosystems under global environmental change [41-44].

However, an increasingly noted shortcoming of these models is their limited representation of phenotypic variability (e.g., $[45,46])$. Most DVMs operate with a fixed phenotype per species or represent the species of the world via a small number of plant functional types (PFTs). This simplistic representation largely neglects the complex patterns of trait variability within and between species. Such patterns occur at all ecological scales $[18,20]$ and across ontogenetic stages. Fixed phenotypes do not account for changes in traits that may occur through plastic and eco-evolutionary dynamics $[15,27]$. Thus, most current models are ill-equipped to explore the consequences of trait variability for ecosystems dynamics or biosphere-atmosphere interactions [1,3]. The lack of processes responsible for trait variability (Figure 1) increases the uncertainties in the predictions provided by DVMs.

In response to these issues, there have been several attempts to establish next-generation vegetation models, which here we summarize as 'plastic, prescribed, and eco-evolutionary' models of trait variability (Box 2; see also the supplemental information online).
${ }^{6}$ Karlsruhe Institute of Technology, Institute for Meteorology and Climate Research, Atmospheric Environmental Research (IMK-IFU), Kreuzeckbahnstrasse 19, Garmisch-Partenkirchen 82467, Germany

${ }^{7}$ Helmholtz Centre for Environmental Research - UFZ, Permoserstraße 15, Leipzig 04318, Germany

${ }^{8}$ Potsdam Institute for Climate Impact Research (PIK), Member of the Leibniz Association, PO Box 6012 03, D-14412 Potsdam, Germany

9Department of Evolutionary Biology, Ecology, and Environmental Sciences, University of Barcelona (UB), Barcelona 08028, Spain

${ }^{10}$ CREAF (Center for Ecological Research and Forestry Applications), Cerdanyola del Vallès 08193, Spain

${ }^{11}$ Thuenen Institut of Forest Ecosystems, Alfred-Moeller-Str. 1, Haus 41/42, 16225 Eberswalde, Germany

12Theoretical Ecology, Faculty of Biology and Preclinical Medicine, University of Regensburg, Universitätsstraße 3, 93053, Regensburg, Germany

${ }^{\star}$ Corresponding author: fabio.berzaghi@Isce.ipsl.fr 


\section{Trends in Ecology \& Evolution}

\section{Box 1. Dynamic Vegetation Models: An Overview}

The overarching goal of dynamic vegetation models is to describe the functioning of vegetated ecosystems by modeling the key processes that drive vegetation dynamics: primary production, competition, and water and nutrient cycles (see also $[40,41])$. These processes are simulated in response to abiotic and biotic drivers.

Models differ in their emphasis on different processes and scales. Some models concentrate on shorter time scales, with a focus on productivity and allocation as well as short-term feedbacks, such as water and nutrients. Other models also consider succession and changes in community structure as a result of mortality, competition, and disturbances [55]. Global models are often used to study general patterns in vegetation composition or can be coupled to climate models to examine vegetation-atmosphere feedbacks [1]. At the local end of the spectrum, we find forest models focusing on ecophysiology, adaptation, and forest management $[41,55]$. Despite these differences in the scale of interest, most models create their predictions by simulating a local community or ecosystem, which is then upscaled to the desired resolution. As a result, most global models can, and are also used to, model stand-scale dynamics. Still, most models do not explicitly consider spatial feedbacks and dynamics. An exception are so-called 'landscape models', which are spatially explicit and can reproduce spatial processes, such as fire or insect outbreaks [64]

Functional diversity is typically implemented by assigning different model parameters for each species or PFT. The main aim of the PFT concept is to reduce the, often large, taxonomic diversity to a small number of manageable vegetation types, such as deciduous temperate forests, evergreen boreal forests, continental grasslands, and so on [86]. An alternative to this species or type-centered paradigm are trait-based models. These drop the species concept in favor of describing individual plants by a set of traits, emerging from general correlations and dependencies, such as the leaf and stem economics spectra (e.g., $[46,56,87])$

'Plastic models of intraspecific variability' emphasize functional plasticity and trade-offs within plants. In such models, plants can, for example, exhibit morphological and/or physiological changes (e.g., in leaf characteristics or allocation strategies) in response to environmental conditions [47-49]. However, these models are limited by the lack of heritable variability. For example, they assume that all individuals of a species in a given environment express the same phenotype and that the adaptation to changes in environmental drivers is instantaneous.

'Models with prescribed intraspecific variability' incorporate nonplastic trait variability into the modeled processes, but do not explain its origin. These models may help to understand the role of trait variability in structuring plant communities; however, their ability to correctly predict the reassembly of communities after disturbance is being challenged. Mounting evidence suggests that evolutionary processes happen on ecological timescales, in particular under strong selection [31,32].

'Eco-evolutionary models' address this shortcoming by simulating intraspecific variability as the result of ecological and evolutionary processes (in particular natural selection, e.g., [50]). Simple eco-evolutionary models draw new individuals from a given trait distribution and let selection act upon them. More sophisticated (and computationally costly) models draw new individuals from the current community following genetic inheritance rules and via explicit models of genotype-phenotype relationships (Box 3). By representing genetic processes, rapid evolution in response to climate change can be more reliably modeled.

\section{Research Priorities for Next-Generation Trait-Flexible Models}

Despite encouraging progress, there is clear potential for a more robust representation of intraspecific trait variability and its genetic origin in DVMs. Here, we outline what we see as research priorities and key challenges for creating a new generation of trait-flexible models that, in principle, would fully account for, and predict, observed variability and plasticity in plant traits and functions.

\section{Understanding Plasticity, Acclimation, and Lagged Effects}

Current DVMs may include limited plasticity at the process-level (e.g., in allocation, phenology, photosynthesis, and autotrophic respiration) [51]. In working towards a more complete treatment
Glossary

Acclimation/acclimatization: plastic response of an individual to environmental change within its lifetime, often important on short timescales (e.g., months or seasons). We consider the two terms to be synonyms in the broadest sense, without a distinction between natural or controlled environments.

Adaptation: genetic response to selection resulting in genetic and phenotypic changes between generations. Natural selection relies on differential fitness of individuals with different phenotypes.

Common garden experiment/ provenance trial: a classic experimental design to test for heritable differences between populations and/or provenances; involves planting seedlings or seeds of the same family or species, but from different geographical origin or context, in the same location. Dynamic vegetation models (DVM, related: land surface models, ecosystem models, process-based vegetation models, terrestrial biosphere models, etc.): a group of models that dynamically simulate the succession, distribution, and structure of natural vegetation, using mostly mechanistic representations of large-scale vegetation processes. Eco-evolutionary dynamics: the interplay of ecological and evolutionary processes on the same timescale.

Ecological strategy: the manner in which a species obtains and uses resources, interacts with other organisms, copes with (and is adapted to) environmental stresses, and, in the end, ensures genetic continuity among generations.

Epigenetic: heritable changes in gene expression that are not caused by mutations of the DNA sequence. The induced phenotypic changes (due, for instance, to DNA methylation) are potentially reversible and, thus, are less stable than changes due to DNA sequence mutation.

Evolvability: the capacity of a biological system for adaptive evolution and, thus, the ability to adapt to future environments through evolutionary processes. 


\section{Trends in Ecology \& Evolution}

\section{CellPress REVIEWS}

\section{Box 2. State-of-the-Art of Models Including Intraspecific Trait Variability}

Within the ecological modeling literature, we identified three main approaches for including plastic trait variability (Table I). A complete list of models and methods is provided in the supplemental information online.

\section{Table I. Three Main Approaches for Including Plastic Trait Variability}

\begin{tabular}{|c|c|}
\hline Feature & Description \\
\hline \multicolumn{2}{|c|}{ Plastic models of intraspecific variability } \\
\hline $\begin{array}{l}\text { General } \\
\text { approach }\end{array}$ & $\begin{array}{l}\text { Plasticity is described through equations of the physiological response to a change in } \\
\text { environmental conditions. For example, acclimation of photosynthesis is described by } \\
\text { an equation describing the response of maximum photosynthetic rate in relation to leaf } \\
\text { nitrogen concentration [48] }\end{array}$ \\
\hline Advantages & $\begin{array}{l}\text { Allows plant responses to be simulated in different environments and ecosystems, } \\
\text { because equations are used to describe the general functioning of plant } \\
\text { ecophysiology }\end{array}$ \\
\hline \multirow[t]{2}{*}{ Limitations } & Difficult to determine generalizable functions applicable to different plants and conditions \\
\hline & $\begin{array}{l}\text { By describing only one plastic response, related counter-responses might be missing } \\
\text { because physiological processes are interrelated }\end{array}$ \\
\hline Examples & PnET-CN [49]; IBM-Esther [47]; ORCHIDEE-NP [48] \\
\hline \multicolumn{2}{|c|}{ Models based on prescribed trait distributions } \\
\hline $\begin{array}{l}\text { General } \\
\text { approach }\end{array}$ & $\begin{array}{l}\text { Well-established trade-offs (e.g., leaf- and wood-economic spectra) are used to assign } \\
\text { and constrain trait values corresponding to model parameters. Trait values are sampled } \\
\text { from empirical trait distributions generated from plant trait databases (e.g., [14]) or local } \\
\text { measurements. Different trait values are assigned to individual plants }\end{array}$ \\
\hline \multirow[t]{3}{*}{ Advantages } & No major modification of model structure necessary \\
\hline & Allows the study of the effects of selection and trait variability \\
\hline & Many data are available for traits across the leaf and stem-economic spectrum \\
\hline \multirow[t]{4}{*}{ Limitations } & $\begin{array}{l}\text { Ongoing adaptation to changing local environmental conditions is not simulated, which } \\
\text { implies no trait evolution }\end{array}$ \\
\hline & No trade-offs or constraints, potentially leading to unrealistic combinations of traits \\
\hline & $\begin{array}{l}\text { A more detailed description of intraspecific and/or interspecific variability is } \\
\text { impossible due to the lack of a mechanistic underpinning corresponding to the real } \\
\text { ecological processes. This limitation makes predictions from such a model somewhat } \\
\text { questionable }\end{array}$ \\
\hline & $\begin{array}{l}\text { Not bound to any particular spatial scale; can represent a large number of combinations } \\
\text { of traits, although it is not clear whether these combinations represent actual species }\end{array}$ \\
\hline Examples & ArcVeg [88]; Ecotone [89]; CABLE [90] \\
\hline \multicolumn{2}{|c|}{ Eco-evolutionary models (species or trait-based) } \\
\hline $\begin{array}{l}\text { General } \\
\text { approach }\end{array}$ & $\begin{array}{l}\text { Concepts from quantitative genetics are used to simulate adaptive evolution; trait } \\
\text { values are determined by the genetic contribution of one to several loci associated with } \\
\text { a particular trait. Trait distributions emerge from some or all of the following processes: } \\
\text { heritability, mutation, gene flow. A detailed example is presented in Box } 3 \text { in the main } \\
\text { text. }\end{array}$ \\
\hline
\end{tabular}

(Continued on next page)
Fitness: expected lifetime reproductive success of a phenotype or genotype, frequently expressed as a result of abiotic and biotic processes.

Genetic architecture: the number of loci determining a given trait and whether a locus acts on several traits (pleiotropy); the number of allele per loci and their effects on each trait, the degree of linkage between loci, and interactions between loci (epistasis). Genotype: a set of genes that determine the phenotype.

Mating system: determines who mates with whom in a species or population, and includes the selfpollination rate, the rate of pollen immigration, and the variances of individual fecundities. The mating system determines the level of genetic drift, the level of inbreeding of the offspring, and, through inbreeding depression, the dynamics of natural

regeneration.

Model parameter: a variable in an equation or algorithm describing (part of) a mechanism or process. In dynamic vegetation models, parameters can define traits or properties of processes included in the model.

Phenotype: a set of traits Phenotypic or trait variability: the variation in phenotypes between species (interspecific) or within and among populations of a species (intraspecific) which can arise from genetic and epigenetic variation, and/or from plastic responses to the environment. Plant functional traits: observable characteristics of a plant, including morphological, physiological, and phenological characteristics. Traits influence the demographic and reproductive performances or ecological functions of a plant.

Plant functional type (PFT): classically refers to aggregating functionally similar species into a single group (i.e., functional type). In principle, PFTs could also be defined to classify variability within a species.

Plasticity: the phenomenon of the same genotype producing different phenotypes in response to different environmental stimuli. Plasticity includes acclimatization/ acclimation. 


\section{Trends in Ecology \& Evolution}

Table I. Continued

\begin{tabular}{|c|c|}
\hline Feature & Description \\
\hline \multirow[t]{9}{*}{ Advantages } & Trait- and species-based models: \\
\hline & $\begin{array}{l}\text { Simulates the rate of adaptation to changes of environmental drivers from first } \\
\text { principles }\end{array}$ \\
\hline & Allows simulating adaptive responses of plastic and nonplastic traits \\
\hline & $\begin{array}{l}\text { The equations controlling the quantitative genetics are first order algebraic (easily } \\
\text { computable) }\end{array}$ \\
\hline & Trait-based models only: \\
\hline & Avoids technical and data limitations associated with working at the species level \\
\hline & $\begin{array}{l}\text { While species-level trait data are often difficult to obtain, community-level } \\
\text { relationships are relatively well described }\end{array}$ \\
\hline & Inter- and intraspecific variability are both covered \\
\hline & $\begin{array}{l}\text { By applying selection on the initial trait space, functional diversity patterns at the } \\
\text { macroscale emerge (e.g., observed clines in traits across environmental gradients) }\end{array}$ \\
\hline \multirow[t]{5}{*}{ Limitations } & $\begin{array}{l}\text { Requires insights into genetic architecture of traits (distribution of allelic effects in the } \\
\text { population, number of alleles and loci determining the trait, interactions between alleles } \\
\text { and/or loci); Until recently, only simple genotype-phenotype relationships have been } \\
\text { included (e.g., no epigenetics or gene activation) }\end{array}$ \\
\hline & Requires knowledge of pollen and seed dispersal as well as mating system \\
\hline & Because of computation costs, only a subset of traits can evolve and need to be selected \\
\hline & Trait-based models only: \\
\hline & $\begin{array}{l}\text { Plants are defined by sets of traits not directly attributable to any species; it is difficult } \\
\text { to connect to species-specific data for validation and initialization purposes }\end{array}$ \\
\hline Examples & aDGVM [56]; FORGEM [76]; PDG [67]; Jedi-DGVM [87] \\
\hline
\end{tabular}

of physiological and morphological plasticity, a first challenge is to create appropriate empirical models. In particular, plasticity as a within-generation response to environmental variability needs to be disentangled from across-generation responses achieved by either epigenetic or genetic inheritance (some examples in Table 1). Representing within-generation lagged effects is especially challenging, such as the effect of past stress (drought, starvation, etc.) on plant traits and future mortality rates. Lagged effects are observed in empirical studies but are not well understood and, thus, are rarely modeled [52]. A first step would be to incorporate some of these lagged effects through dynamic functions that relate disturbance events to physiological responses [52-54].

\section{Closing the Demographic Loop}

For modeling eco-evolutionary dynamics, we also have to determine the fitness of any given phenotype or genotype. Many existing vegetation models are not particularly well suited for this task [39] also due to a limited description of mortality and recruitment processes [39,55], arguably because the primary focus of past model development has been on growth (individual-tree and stand-scale models), productivity, and carbon cycling (global models). Many widely used models simulate recruitment via a constant seed rain, making reproduction independent from the performance of traits or species in the standing community (but see [56]). This is clearly inadequate to simulate evolution.

\section{CellPress REVIEWS}

Provenance: variety of a tree species from a well-defined geographical area.

Rapid evolution: the response to selection within a few generations (e.g., through selection on standing diversity and recombination). (Natural) selection: the main mechanism of evolution relying on differential survival and/or reproductive success of individuals with different phenotypes. Selection affects the standing diversity. Standing diversity: existing genetic diversity within a population. Trade-off: describes situations where further investment of resources in some trait or process necessitates less investment in another trait or process. 


\section{Trends in Ecology \& Evolution}

Box 3. Integrating Physiology, Demography, and Genetics in Forest Trees with Physio-Demo-Genetic Models

Physio-demo-genetic (PDG) models integrate physiological, demographic, and evolutionary processes. They have been developed to better understand the interplay among plasticity and genetic adaptation and the effects of both processes on tree population dynamics under global change $[67,76,91]$. The advantage of PDG models is their ability to account for the variability in functional traits due to both standing genetic variation and evolutionary change in response to changing local environmental conditions.

In such models, trait values are modeled following a classical quantitative genetic model (Figure IA) and, thus, are inherited by the offspring of a tree. Given that reproduction, growth, and survival of individual trees depend on their particular trait constellation, the interaction between the biophysical and the demographic models results in a trait-fitness relationship for the particular environmental conditions. PDGs have been applied to examine the adaptation of the timing of budburst (TBB) along altitudinal or latitudinal gradients of Fagus sylvatica (the European beech). Simulations show that only a few generations were sufficient to develop nonmonotonic genetic differentiation in the TBB along the local climatic gradient (Figure IB).

(A)

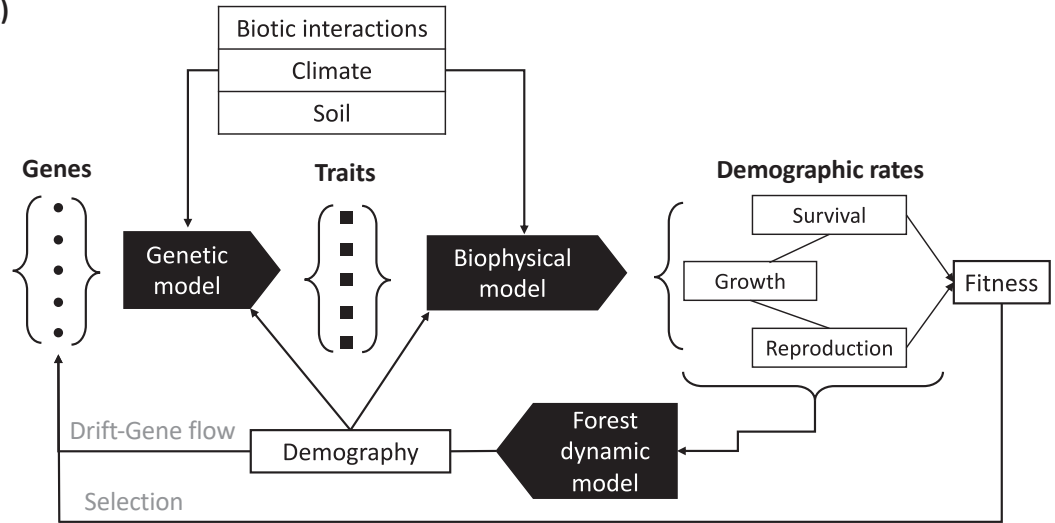

(B)

(i)

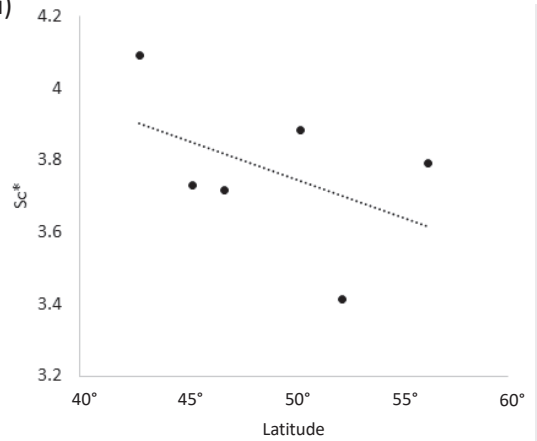

(ii)

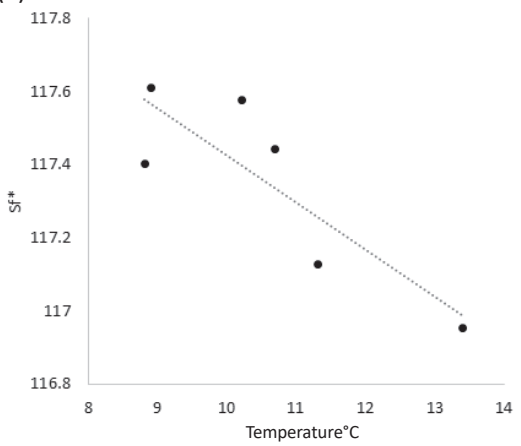

Trends in Ecology \& Evolution

Figure I. Physio-Demo-Genetic (PDG) Models: Outline and an Application.

(A) Conceptual framework of PDG models. PDG models couple: (i) a biophysical module to simulate carbon and water fluxes at the tree level using climate observations; (ii) a forest dynamics module to calculate demographic rates for adult trees (growth, mortality, and reproduction) based on carbohydrate reserves, and to simulate ecological processes across the life cycle; and, (iii) a quantitative genetics module relating genotype to the phenotype of one or more functional traits. (B) (i) Latitudinal cline of chilling (i.e., low temperature) requirements $\left(\mathrm{Sc}^{\star}\right)$ and (ii) dependency of forcing (i.e., high temperature) requirements $\left(\mathrm{Sf}^{\star}\right)$ on average temperature after 400 years of simulation. Initially, both $\mathrm{Sc}^{*}$ and $\mathrm{Sf}^{*}$ start with a single value at all locations. Reproduced from [76]. 


\section{Trends in Ecology \& Evolution}

Table 1. Traits with their Reported Sources of Intraspecies Variability Categorized by Class or Process Type, Followed by Key Empirical Correlations or Constraints and DVMs, Including a Trait-Flexible Implementation ${ }^{a, b, c, d}$

\begin{tabular}{|c|c|c|c|c|c|c|}
\hline $\begin{array}{l}\text { Class/ } \\
\text { process }\end{array}$ & Trait & $\begin{array}{l}\text { Reported } \\
\text { within-species } \\
\text { variation: } \\
\text { source not } \\
\text { distinguished }\end{array}$ & $\begin{array}{l}\text { Evidence for } \\
\text { genetic and/or } \\
\text { epigenetic link } \\
\text { to variation }\end{array}$ & $\begin{array}{l}\text { Variation } \\
\text { from } \\
\text { plasticity }\end{array}$ & $\begin{array}{l}\text { Empirical key } \\
\text { correlations or } \\
\text { constraints with other } \\
\text { traits or processes }\end{array}$ & $\begin{array}{l}\text { Trait } \\
\text { variability in } \\
\text { current } \\
\text { models }\end{array}$ \\
\hline \multirow[t]{4}{*}{ Photosynthesis } & $\begin{array}{l}\text { Maximum } \\
\text { photosynthetic } \\
\text { rate, } V_{c \max }\end{array}$ & [92] & [93] & [93-96] & $\begin{array}{l}\text { Positively correlated with } \\
\text { leaf nitrogen, phosphorous, } \\
\text { and specific leaf area [94,97- } \\
\text { 99] }\end{array}$ & $\begin{array}{l}\text { LPJmL-FIT } \\
\text { [46], MATEY } \\
\text { [85] }\end{array}$ \\
\hline & $\begin{array}{l}\text { Leaf mass per } \\
\text { area }\left(\mathrm{g} \mathrm{m}^{-2}\right) \text { or } \\
\text { its inverse, } \\
\text { specific leaf } \\
\text { area }\left(\mathrm{cm}^{2} \mathrm{~g}^{-1}\right)\end{array}$ & [100-103] & {$[27,104-107]$} & [95] & $\begin{array}{l}\text { Correlated negatively with } \\
\text { leaf lifespan, positively with } \\
\text { leaf nitrogen, phosphorous, } \\
\text { and dark respiration }[13,86] \text {. } \\
\text { Higher in more arid sites and } \\
\text { at higher irradiance } \\
{[108,109]}\end{array}$ & $\begin{array}{l}\text { LPJmL-fit [46], } \\
\text { MATEY [85], } \\
\text { LM3-PPA [110] }\end{array}$ \\
\hline & $\begin{array}{l}\text { Nitrogen content } \\
\left(\mathrm{g} \mathrm{m}^{-2}\right)\end{array}$ & {$[102,103]$} & {$[27,107,111]$} & [71] & $\begin{array}{l}\text { Higher in more arid sites and } \\
\text { at higher irradiance } \\
{[108,112]}\end{array}$ & $\begin{array}{l}\text { CABLE [90], } \\
\text { MATEY [85], } \\
\text { TFS [113] }\end{array}$ \\
\hline & $\begin{array}{l}\text { Stomatal } \\
\text { conductance (gw) }\end{array}$ & [114] & {$[27,115]$} & {$[116,117]$} & $\begin{array}{l}\text { Assimilation rate; higher in } \\
\text { low soil phosphorus sites } \\
{[118]}\end{array}$ & - \\
\hline \multirow[t]{3}{*}{ Respiration } & $\begin{array}{l}\text { Proportional } \\
\text { change in } \\
\text { respiration per } \\
10^{\circ} \mathrm{C} \text { increase in } \\
\text { temperature }\left(\mathrm{Q}_{10}\right)\end{array}$ & [119] & - & {$[120,121]$} & $\begin{array}{l}\text { Two types of acclimation: (i) } \\
\text { adjustments in the } \mathrm{Q}_{10} \text {; and } \\
\text { (ii) changes in enzymatic } \\
\text { capacity of respiratory } \\
\text { system }\end{array}$ & PnET-CN [49] \\
\hline & $\begin{array}{l}\text { Number of } \\
\text { mitochondria } \\
\text { per cell }\end{array}$ & [122] & - & [123] & $\begin{array}{l}\text { Respiration, growth, } \\
\text { acclimation at high } \mathrm{CO}_{2} \text { [123] }\end{array}$ & - \\
\hline & $\begin{array}{l}\text { Leaf respiration } \\
\text { in darkness and } \\
\text { in light }\end{array}$ & [103] & [27] & {$[95,120]$} & $\begin{array}{l}\text { Leaf dark respiration varies in } \\
\text { relation to site climate [124] }\end{array}$ & LM3-PPA [110] \\
\hline \multirow[t]{3}{*}{$\begin{array}{l}\text { Wood/leaf } \\
\text { structure }\end{array}$} & Wood density & {$[125,126]$} & {$[104,127,128]$} & [129] & $\begin{array}{l}\text { Connections to growth rate } \\
\text { and mortality. Higher in } \\
\text { more arid sites [125] }\end{array}$ & $\begin{array}{l}\text { LPJmL-FIT } \\
\text { [46], aDGVM2 } \\
\text { [56], TFS [113] }\end{array}$ \\
\hline & $\begin{array}{l}\text { Wood and } \\
\text { sapwood hydraulic } \\
\text { conductivity and } \\
\text { anatomy (vessel } \\
\text { lumen area, ring } \\
\text { width). Hydraulic } \\
\text { plasticity and P50 }\end{array}$ & {$[126,130]$} & {$[104,128]$} & [131-135] & $\begin{array}{l}\text { Globally, higher in wetter } \\
\text { sites and in warmer sites } \\
{[136,137]}\end{array}$ & - \\
\hline & $\begin{array}{l}\text { Herbivory defense } \\
\text { (e.g., plant } \\
\text { secondary }\end{array}$ & [138] & [138-141] & [142] & $\begin{array}{l}\text { Trade-off between defense } \\
\text { and growth influences } \\
\text { allocation strategies [143]. }\end{array}$ & - \\
\hline
\end{tabular}


Table 1. Continued

\begin{tabular}{|c|c|c|c|c|c|c|}
\hline $\begin{array}{l}\text { Class/ } \\
\text { process }\end{array}$ & Trait & $\begin{array}{l}\text { Reported } \\
\text { within-species } \\
\text { variation: } \\
\text { source not } \\
\text { distinguished }\end{array}$ & $\begin{array}{l}\text { Evidence for } \\
\text { genetic and/or } \\
\text { epigenetic link } \\
\text { to variation }\end{array}$ & $\begin{array}{l}\text { Variation } \\
\text { from } \\
\text { plasticity }\end{array}$ & $\begin{array}{l}\text { Empirical key } \\
\text { correlations or } \\
\text { constraints with other } \\
\text { traits or processes }\end{array}$ & $\begin{array}{l}\text { Trait } \\
\text { variability in } \\
\text { current } \\
\text { models }\end{array}$ \\
\hline & $\begin{array}{l}\text { metabolites, } \\
\text { spines) or serotiny } \\
\text { (fire resistance) }\end{array}$ & & & & & \\
\hline & Bark thickness & [144] & {$[145,146]$} & [145] & $\begin{array}{l}\text { Thicker in sites with more } \\
\text { frequent fire and/or more } \\
\text { frequent and/or severe } \\
\text { drought, and hotter sites } \\
{[144,147,148]}\end{array}$ & LPX [149] \\
\hline \multirow[t]{3}{*}{ Phenology } & $\begin{array}{l}\text { Timing of } \\
\text { budburst }\end{array}$ & [150] & [151-153] & [151] & $\begin{array}{l}\text { Constraints: duration of } \\
\text { growing season versus frost } \\
\text { damage }[24,153]\end{array}$ & $\begin{array}{l}\text { Forgem [76], } \\
\text { PDG [67] }\end{array}$ \\
\hline & $\begin{array}{l}\text { Timing of leaf } \\
\text { fall/growth } \\
\text { cessation }\end{array}$ & [154] & [24] & [155] & $\begin{array}{l}\text { Constraints: duration of } \\
\text { growing season versus frost } \\
\text { damage }[24,153] \text {. Nutrient } \\
\text { resorption [154] }\end{array}$ & - \\
\hline & Frost hardiness & - & [27] & {$[156,157]$} & $\begin{array}{l}\text { Constraints: duration of } \\
\text { growing season versus frost } \\
\text { damage [156] }\end{array}$ & $\begin{array}{l}\text { Forgem, } \\
\text { Forgro [76] }\end{array}$ \\
\hline \multirow[t]{2}{*}{ Allocation } & $\begin{array}{l}\text { Biomass } \\
\text { compartments, } \\
\text { allometries } \\
\text { (leaf:fine root, } \\
\text { diameter:height) }\end{array}$ & [158] & {$[27,105,111]$} & {$[111,159]$} & $\begin{array}{l}\text { Growth, stem, and leaf } \\
\text { economics spectra }\end{array}$ & $\begin{array}{l}\text { Jedi-DGVM } \\
\text { [87], aDGVM2 } \\
{[56]}\end{array}$ \\
\hline & $\begin{array}{l}\text { Leaf } \\
\text { area:sapwood } \\
\text { area ratio }\end{array}$ & [126] & [104] & {$[131,132]$} & $\begin{array}{l}\text { Globally, lower in drier sites } \\
\text { and in species with smaller } \\
\text { leaves and/or lower specific } \\
\text { leaf area [137] }\end{array}$ & - \\
\hline \multirow[t]{2}{*}{ Reproduction } & Seed size & {$[160,161]$} & [162] & {$[57,163]$} & $\begin{array}{l}\text { Height, seedling survival, } \\
\text { dispersal distance }[8,160]\end{array}$ & $\begin{array}{l}\text { Hybrid-DVM } \\
{[164], \text { aDGMV2 }} \\
{[56]}\end{array}$ \\
\hline & Germination rate & [161] & {$[27,105]$} & [165] & Recruitment & $\begin{array}{l}\text { Esther individual-based } \\
\text { model [47] }\end{array}$ \\
\hline
\end{tabular}

${ }^{a}$ The full list of models and details on their implementation of flexible traits can be found in the supplemental information online.

${ }^{b}$ The source of variability, when determined, is classified as plastic or genetic or both. It also provides a brief description of key correlation with other traits and processes.

${ }^{\mathrm{C}} \mathrm{A}$ list of examples is presented in which DVMs have implemented trait variability for the specified trait.

'This table is not an exhaustive list; thus, more references in a cell do not necessarily imply a higher number of studies; where possible, at least two examples per cell were included. Primary literature was preferred over review articles. The full list of models and reviewed articles can be found in the supplemental information online. ep50: water potential at which $50 \%$ of hydraulic conductivity is lost.

Moreover, a lot is known about variability in seed production and seed size and the implications for plant demography (e.g., $[8,17,57])$, yet relatively little use is made of this knowledge (but see $[58,59])$. Other entry points to simulate plasticity across life stages are changes in allocation to plant defenses 


\section{Trends in Ecology \& Evolution}

[60] and ontogenetic shifts in leaf traits [61]. Ultimately, without realistic descriptions of all three demographic processes (reproduction, growth, and mortality) (i.e., 'closing the demographic loop'), we cannot generate realistic predictions about how selection influences the distribution of observed phenotypes at local scales, especially in variable environments.

\section{Space and Dispersal}

Evolutionary models often assume well-mixed populations, but we know that genetic and phenotypic variation in plants show strong spatial structure. Few models incorporate key mechanisms for predicting shifts in the ranges of species [62]. Furthermore, spatial processes are needed to study plant responses when climatic and nonclimatic agents of selection are decoupled [63]. When trying to represent these structures and processes in DVMs, we face the problem that most DVMs are not spatially explicit. Typically, they produce maps based on independently simulated communities (e.g., from $25 \mathrm{~m} \times 25 \mathrm{~m}$ up to several hectares), which are then averaged to create large-scale maps. In principle, the knowledge and data for a better representation of spatial processes are often available. Yet, it can be prohibitively complex to track pollen and seeds or to follow the germination and growth of a large number of offspring. However, recent examples show some solutions to implement spatial processes, such as dispersal and pollination, at various geographical scales (i.e., local to continental) [64-67].

\section{Trade-Offs}

Any eco-evolutionary model will have to define appropriate trade-offs to constrain species properties to ecophysiologically realistic values, and to avoid unbeatable (and unrealistic) 'superspecies' (or supergenotypes) emerging and taking over. A pragmatic approach $[46,56]$ is to represent key trade-offs using observed trait correlations (e.g., the leaf economics spectrum [13]). Another option is to incorporate theory for specific trade-offs, such as concerning seed and seedling competition versus colonization abilities [57], water and nutrient use in photosynthesis [68], or biomass allocation to different plant parts (e.g., [69]). A further approach is to better define trait-climate relationships using combined trait and flux data, allowing one to develop dynamic acclimation functions [70]. Still, some fundamental questions remain; most notably, the extent to which trade-offs among traits are general within species as well as across taxonomic groups, and independent of other plant parameters [19]. Increasingly detailed quantification of geographic trait variation (e.g., [71]) will facilitate a better representation of local adaptation [72] and overcome some of the limitations described in Box 2.

\section{Epigenetic Inheritance}

Current DVMs do not consider that plastic responses can be propagated across generations via epigenetic mechanisms [73]. These effects are probably more significant and have a shorter response time than genetically inherited effects $[22,63,73]$. The main challenge of implementing epigenetic processes is our lack of precise knowledge about them: there is abundant empirical evidence for epigenetic regulation in nonnatural environments, but we lack data to make predictive models for natural situations. Limited knowledge of epigenetic mechanisms makes their implementation a low priority, until high-throughput sequencing provides sufficiently abundant quantitative data linking them to evolutionary processes [73].

\section{Genetic Architecture and the Genotype-Phenotype Link}

Many eco-evolutionary models of trait evolution assume that mutations act directly on traits $[56,74,75]$. In reality, mutations act on genes and, thus, only indirectly on traits via genotypephenotype links. Accounting for recombination, genetic architecture of traits, and any deviation from random mating can lead to important differences in the rate of adaptation simulated by gene-based evolution models compared with trait-based evolution models. In particular, recombination enables considerably faster creation of new phenotypes from an existing gene pool compared with mutation. The ways in which genetic architecture drives trait evolution are still debated. However, enough knowledge is available to couple basic evolutionary models with explicit genetic structure to DVMs and other ecological models $[50,67,76]$ (Box 3). Accounting for the rate of adaptation of traits is most important for: (i) short-lived plants; (ii) ecosystems with frequent generational changes due to high disturbance rates or forest management; and (iii) tree populations at 


\section{Trends in Ecology \& Evolution}

the edge of their distributions [77]. Yet, a key problem in these models is predicting phenotypes from genotypes and environment; this requires data and knowledge that are still unavailable for many tree species and traits of interest, and are often population specific. Another challenge is scaling up these processes to large spatial and timescales to understand adaptation processes, such as gene flow and reproductive isolation across the ranges of species (also see the following section 'Efficient Scaling').

\section{Efficient Scaling across Several Space or Timescales}

Implementing many of the processes described earlier invokes an old, but still unresolved issue in theoretical ecology: the problem of upscaling the effects of local or short-term processes (dispersal or microevolution) to large temporal and spatial scales [78]. Aside from the inevitable technical considerations, it is important to consider that patterns of trait variability might not hold across geographical and ecological scales $([19,79])$. These findings have implications for DVMs because global trait parameters, even if flexible, might add uncertainty when upscaling local ecosystem properties. More fundamental research is needed on the subject. For now, a practical and partial solution would be to use georeferenced trait data when determining tradeoffs and, when available, local trait data (see earlier 'Trade-Off' section).

\section{Model-Data Integration}

Finally, a crucial point for the utility of new model structures is their ability to use and integrate existing data. General approaches for model-data integration have been discussed elsewhere (e.g., [40]). The core of this discussion is that data can enter the model at different levels, as inputs, drivers, or prior information on model parameters or on model outputs, the latter requiring inverse modeling to back-propagate output data to infer model parameters or states. These general insights remain valid for the problem we tackle here, but, in practice, the question will be whether sufficient data are available to constrain DVMs and where in these models are the data best placed to constrain key processes.

The most obvious data type to consider is trait data (Table 1). For example, the TRY database currently holds $\sim 12$ million trait records from 280000 species. For further trait databases, see [14], eFloweri , and the China Plant Trait Database [80]. Not all trait records map 1:1 to model parameters, but these databases are clearly a key data source for creating priors on model parameters and tradeoffs, or to obtain data on outputs for those model types in which trait distributions are emergent. There are many other, more specialized data types that are also interesting. For example, data from provenance experiments contain information about heritable intraspecific differences, in particular regarding leaf properties (morphology and chemistry), bud burst, phenology, photosynthetic and hydraulic physiology, and other quantitative traits [81]. Both historical and current data from provenance trials are being used for quantitative genetic studies, but these data are underutilized for parameterizing models.

\section{Concluding Remarks and Future Directions}

Most current DVMs describe species or PFTs by a single set of properties that are static in space and time. Empirical data show that this is a crude approximation at best, because genetic and phenotypic diversity allow for plastic responses and long-term adaptations to environmental conditions, also via epigenetic inheritance.

We suggest that a new generation of trait-flexible vegetation models is needed that embraces the variability and adaptability of functional traits in vegetated ecosystems. An ideal model would explicitly account for phenotypic plasticity as well as genetic and epigenetic mechanisms in a spatiotemporal context. Such a model would not only allow researchers to quantify the degree to which trait variability buffers diversity and ecosystem functioning against climate change, but also improve our mechanistic understanding of the processes contributing to trait diversity and, thus, biodiversity. Trait-flexible models could help separate the heritable components of trait variability from plastic components, across-generational trait variability, and the influence of biotic and abiotic factors. 


\section{Trends in Ecology \& Evolution}

Celliress
Inclusion of a wider range of flexible traits could further help determining the individual contribution of certain traits to plant fitness.

One risk of adding additional processes to existing models is that they become increasingly complex, difficult to parameterize, and, thus, prone to higher uncertainty $[82,83]$. Countering that is the potential to increasingly rely on optimality-based approaches in model components. In principle, these approaches should allow models to be at least as powerful as standard approaches but would require fewer inputs (e.g., $[68,69,84,85])$. In practice, compromises will have to be made between accuracy, realism, and generality [83] (see Outstanding Questions), but we believe that immediate progress is possible in the areas that we have highlighted here.

\section{Acknowledgments}

This article is an outcome of the COST Action FP1304 PROFOUND (Towards Robust Projections of European Forests under Climate Change), supported by COST (European Cooperation in Science and Technology, www.cost.eu). F.B. was funded by the CEA Enhanced Eurotalents Fellowship (a Marie Sklodowska-Curie Actions Programme), the University of Tuscia doctoral program, and the European Union's Horizon 2020 research and innovation programme Marie Sklodowska-Curie grant No 845265. F.J.B. and I.J.W. acknowledge support from the Australian Research Council, grant DP170103410. C.P.O.R. acknowledges financial support from the Germany Ministry for Education and Research (BMBF, 01LS1711A). F.H. acknowledges funding from the Bavarian Climate Research Network bayklif via the research project BLIZ. We would like to thank A. Collalti for providing feedback on the manuscript.

\section{Supplemental Information}

Supplemental information associated with this article can be found online at https://doi.org/10.1016/ j.tree.2019.11.006.

\section{Resources}

iwww.try-db.org

iihttp://eflower.myspecies.info/

\section{References}

1. Bonan, G.B. (2008) Forests and climate change: forcings, feedbacks, and the climate benefits of forests. Science 320, 1444-1449

2. Le Quéré, C. et al. (2016) Global carbon budget 2016. Earth Syst. Sci. Data 8, 605-649

3. Song, Z. et al. (2012) Plant impact on the coupled terrestrial biogeochemical cycles of silicon and carbon: implications for biogeochemical carbon sequestration. Earth-Sci. Rev. 115, 319-331

4. Daily, G.C. (1997) Nature's Services: Societal Dependence on Natural Ecosystems, Island Press

5. Jump, A.S. and Peñuelas, J. (2005) Running to stand still: adaptation and the response of plants to rapid climate change. Ecol. Lett. 8, 1010-1020

6. Loehle, C. (1988) Problems with the triangular model for representing plant strategies. Ecology 69, 284-286

7. Grime, J.P. (1977) Evidence for the existence of three primary strategies in plants and its relevance to ecological and evolutionary theory. Am. Nat. 111, 1169-1194

8. Westoby, M. (1998) A leaf-height-seed (LHS) plant ecology strategy scheme. Plant Soil 199, 213-227

9. Lavorel, S. and Garnier, E. (2002) Predicting changes in community composition and ecosystem functioning from plant traits: revisiting the Holy Grail. Funct. Ecol. 16, 545-556
10. Aubin, l. et al. (2016) Traits to stay, traits to move: a review of functional traits to assess sensitivity and adaptive capacity of temperate and boreal trees to climate change. Environ. Rev. 24, 164-186

11. Reich, P.B. et al. (1999) Generality of leaf trait relationships: a test across six biomes. Ecology 80, 1955-1969

12. Niinemets, Ü. (1999) Research review. Components of leaf dry mass per area thickness and density - alter leaf photosynthetic capacity in reverse directions in woody plants. New Phytol. 144, 35-47

13. Wright, I.J. et al. (2004) The worldwide leaf economics spectrum. Nature 428, 821-827

14. Schneider, F.D. et al. (2019) Towards an ecological trait-data standard. Methods Ecol. Evol. Published online August 19. 2019. https://doi.org/10.1111/ 2041-210X.13288

15. Kunstler, G. et al. (2015) Plant functional traits have globally consistent effects on competition. Nature 529, 204 of functional biogeography. Proc. Natl. Acad. Sci. U. S. A. 111, 13690-13696

17. Adler, P.B. et al. (2014) Functional traits explain variation in plant life history strategies. Proc. Natl. Acad. Sci. U. S. A. 111, 740-745
16. Violle, C. et al. (2014) The emergence and promise

\section{Outstanding Questions}

How can we best enhance our understanding of the extent, spatial patterns, and trade-offs underpinning intraspecific and interspecific variability of key plant functional traits?

What is the relative importance of inheritance of intraspecific trait variability (across generations determined by genetic and epigenetic mechanisms) compared with trait plasticity (within generation, by the same genotype of even the same individual as shaped by environmental variability)?

How can we best represent links between genotypes and phenotypes in models and, thus, link data on trait variability to genetic and genomic data?

Which processes and predictions are most sensitive to intraspecific trait variability and, thus, which traits and processes should be prioritized in dynamic vegetation models to include trait variability? We provide general guidelines to determine the relative importance of traits for including their variability in models.

How can we model processes that drive trait variability? Specifically, can we build models in which trait variability emerges from demographic processes (i.e., production and dispersal of pollen and seeds, establishment , and mortality), and models of quantitative genetics and plasticity?

How can we deal with spatial heterogeneity in DVMs? Representing spatial patterns might require tracking individual trait and/or genetic variability, with substantial computational costs and more extended use of parallelization and multithreading computational algorithms. 
18. Carnicer, J. et al. (2013) Contrasting trait syndromes in angiosperms and conifers are associated with different responses of tree growth to temperature on a large scale. Front. Plant Sci. 4, 409

19. Messier, J. et al. (2017) Trait variation and integration across scales: is the leaf economic spectrum present at local scales? Ecography 40, 685-697

20. Moran, E.V. et al. (2016) Intraspecific trait variation across scales: implications for understanding global change responses. Glob. Change Biol. 22, 137-150

21. Siefert, A. et al. (2015) A global meta-analysis of the relative extent of intraspecific trait variation in plant communities. Ecol. Lett. 18, 1406-1419

22. Gonzalez, A. et al. (2013) Evolutionary rescue: an emerging focus at the intersection between ecology and evolution. Philos. Trans. R. Soc. B Biol. Sci. 368, 20120404

23. Bolnick, D.I. et al. (2011) Why intraspecific trait variation matters in community ecology. Trends Ecol. Evol. 26, 183-192

24. Savolainen, O. et al. (2007) Gene flow and local adaptation in trees. Annu. Rev. Ecol. Evol. Syst. 38, 595-619

25. Valladares, F. et al. (2014) The effects of phenotypic plasticity and local adaptation on forecasts of species range shifts under climate change. Ecol. Lett. 17, 1351-1364

26. Violle, C. et al. (2012) The return of the variance: intraspecific variability in community ecology. Trends Ecol. Evol. 27, 244-252

27. Alberto, F.J. et al. (2013) Potential for evolutionary responses to climate change - evidence from tree populations. Glob. Change Biol. 19, 1645-1661

28. Rehfeldt, G.E. (1989) Ecological adaptations in Douglas-Fir (Pseudotsuga menziesii var. glauca): a synthesis. For. Ecol. Manag. 28, 203-215

29. Rehfeldt, G.E. et al. (2002) Intraspecific responses to climate in Pinus sylvestris. Glob. Change Biol. 8, 912-929

30. Franks, S.J. et al. (2014) Evolutionary and plastic responses to climate change in terrestrial plant populations. Evol. Appl. 7, 123-139

31. Marina, Alberti et al. (2017) Urban driven phenotypic changes: empirical observations and theoretical implications for eco-evolutionary feedback. Philos. Trans. R. Soc. B Biol. Sci. 372, 20160029

32. Franks, S.J. et al. (2007) Rapid evolution of flowering time by an annual plant in response to a climate fluctuation. Proc. Natl. Acad. Sci. U. S. A. 104, 12781282

33. Stapley, J. et al. (2010) Adaptation genomics: the next generation. Trends Ecol. Evol. 25, 705-712

34. Rudman, S.M. et al. (2018) What genomic data can reveal about eco-evolutionary dynamics. Nat. Ecol. Evol. 2, 9-15

35. Valladares, F. et al. (2015) Species coexistence in a changing world. Front Plant Sci. 6, 866

36. Snell, R.S. et al. (2019) Consequences of intraspecific variation in seed dispersal for plant demography, communities, evolution and global change. AoB PLANTS 11, plz016

37. Hart, S.P. et al. (2016) How variation between individuals affects species coexistence. Ecol. Lett. 19, 825-838

38. Merilä, J. and Hendry, A.P. (2014) Climate change, adaptation, and phenotypic plasticity: the problem and the evidence. Evol. Appl. 7, 1-14

39. Fisher, R.A. et al. (2018) Vegetation demographics in Earth System Models: a review of progress and priorities. Glob. Change Biol. 24, 35-54

40. Hartig, F. et al. (2012) Connecting dynamic vegetation models to data - an inverse perspective. J. Biogeogr. 39, 2240-2252
41. Snell, R.S. et al. (2014) Using dynamic vegetation models to simulate plant range shifts. Ecography 37, 1184-1197

42. Cheaib, A. et al. (2012) Climate change impacts on tree ranges: model intercomparison facilitates understanding and quantification of uncertainty. Ecol. Lett. 15, 533-544

43. Sitch, S. et al. (2008) Evaluation of the terrestrial carbon cycle, future plant geography and climatecarbon cycle feedbacks using five Dynamic Globa Vegetation Models (DGVMs). Glob. Change Biol. 14, 2015-2039

44. Warszawski, L. et al. (2014) The Inter-Sectoral Impact Model Intercomparison Project (ISI-MIP): Project framework. Proc. Natl. Acad. Sci. U. S. A. 111, 3228-3232

45. Bodegom, P.M.V. et al. (2012) Going beyond limitations of plant functional types when predicting global ecosystem-atmosphere fluxes: exploring the merits of traits-based approaches. Glob. Ecol. Biogeogr. 21, 625-636

46. Sakschewski, B. et al. (2015) Leaf and stem economics spectra drive diversity of functional plant traits in a dynamic global vegetation model. Glob. Change Biol. 21, 2711-2725

47. Esther, A. et al. (2011) Low-dimensional trade-offs fail to explain richness and structure in species-rich plant communities. Theor. Ecol. 4, 495-511

48. Goll, D.S. et al. (2017) A representation of the phosphorus cycle for ORCHIDEE (revision 3985). Geosci. Model Dev. Discuss. 2017, 1-39

49. Wythers, K.R. et al. (2013) Incorporating temperature-sensitive Q10 and foliar respiration acclimation algorithms modifies modeled ecosystem responses to global change. J. Geophys. Res. Biogeosciences 118, 77-90

50. Cotto, O. et al. (2017) A dynamic eco-evolutionary model predicts slow response of alpine plants to climate warming. Nat. Commun. 8, 15399

51. Smith, N.G. and Dukes, J.S. (2013) Plant respiration and photosynthesis in global-scale models: incorporating acclimation to temperature and $\mathrm{CO} 2$. Glob. Change Biol. 19, 45-63

52. Keenan, T.f. et al. (2012) Terrestrial biosphere model performance for inter-annual variability of land-atmosphere CO2 exchange. Glob. Change Biol. 18, 1971-1987

53. Kannenberg, S.A. et al. (2019) Linking drought legacy effects across scales: from leaves to tree rings to ecosystems. Glob. Change Biol. 25, 29782992

54. Reyer, C.P.O. et al. (2017) Are forest disturbances amplifying or canceling out climate changeinduced productivity changes in European forests? Environ. Res. Lett. ERL Web Site 12, 034027

55. Bugmann, H. et al. (2019) Tree mortality submodels drive simulated long-term forest dynamics: assessing 15 models from the stand to global scale. Ecosphere 10, e02616

56. Scheiter, S. et al. (2013) Next-generation dynamic global vegetation models: learning from community ecology. New Phytol. 198, 957-969

57. Westoby, M. et al. (2002) Plant ecological strategies: some leading dimensions of variation between species. Annu. Rev. Ecol. Syst. 33, 125-159

58. Vacchiano, G. et al. (2018) Reproducing reproduction: how to simulate mast seeding in forest models. Ecol. Model. 376, 40-53

59. Johnson, J.S. et al. (2019) Rapid changes in seed dispersal traits may modify plant responses to global change. AoB PLANTS 11, plz020

60. Barton, K.E. and Koricheva, J. (2010) The ontogeny of plant defense and herbivory: characterizing general patterns using meta-analysis. Am. Nat. 175, 481-493 
61. Niinemets, Ü. (2006) The controversy over traits conferring shade-tolerance in trees: ontogenetic changes revisited. J. Ecol. 94, 464-470

62. Romero-Mujalli, D. et al. (2019) Individual-based modeling of eco-evolutionary dynamics: state of the art and future directions. Reg. Environ. Change 19, $1-12$

63. Anderson, J.T. (2016) Plant fitness in a rapidly changing world. New Phytol. 210, 81-87

64. Seidl, R. et al. (2012) An individual-based process model to simulate landscape-scale forest ecosystem dynamics. Ecol. Model. 231, 87-100

65. Snell, R.S. (2014) Simulating long-distance seed dispersal in a dynamic vegetation model. Glob. Ecol. Biogeogr. 23, 89-98

66. Kuparinen, A. et al. (2010) Increased mortality can promote evolutionary adaptation of forest trees to climate change. For. Ecol. Manag. 259, 1003-1008

67. Oddou-Muratorio, S. and Davi, H. (2014) Simulating local adaptation to climate of forest trees with a Physio-Demo-Genetics model. Evol. Appl. 7, 453-467

68. Prentice, I.C. et al. (2014) Balancing the costs of carbon gain and water transport: testing a new theoretical framework for plant functional ecology. Ecol. Lett. 17, 82-91

69. Franklin, O. et al. (2012) Modeling carbon allocation in trees: a search for principles. Tree Physiol. 32, 648-666

70. Peaucelle, M. et al. (2019) Covariations between plant functional traits emerge from constraining parameterization of a terrestrial biosphere model. Glob. Ecol. Biogeogr. 28, 1351-1365

71. Dong, N. et al. (2017) Leaf nitrogen from first principles: field evidence for adaptive variation with climate. Biogeosciences 14, 481-495

72. Garzón, M.B. et al. (2019) $\Delta$ TraitSDMs: species distribution models that account for local adaptation and phenotypic plasticity. New Phytol. $222,1757-1765$

73. Richards, C.L. et al. (2017) Ecological plant epigenetics: evidence from model and non-model species, and the way forward. Ecol. Lett. 20, 15761590

74. Laaka-Lindberg, S. and Heino, M. (2001) Clonal dynamics and evolution of dormancy in the leafy hepatic Lophozia silvicola. Oikos 94, 525-532

75. Warren, J. and Topping, C. (2001) Trait evolution in an individual-based model of herbaceous vegetation. Evol. Ecol. 15, 15-35

76. Kramer, K. et al. (2015) Bring in the genes: geneticecophysiological modeling of the adaptive response of trees to environmental change. With application to the annual cycle. Front. Plant Sci. 5, 742

77. Fady, B. et al. (2016) Evolution-based approach needed for the conservation and silviculture of peripheral forest tree populations. For. Ecol. Manag. 375, 66-75

78. Levin, S.A. (1992) The problem of pattern and scale in ecology: The Robert H. MacArthur Award Lecture. Ecology 73, 1943-1967

79. Kumordzi, B.B. et al. (2019) Geographic scale and disturbance influence intraspecific trait variability in leaves and roots of North American understorey plants. Funct. Ecol. 33, 1771-1784

80. Wang, H. et al. (2018) The China Plant Trait Database: toward a comprehensive regional compilation of functional traits for land plants. Ecology 99, 500

81. Sork, V.L. et al. (2013) Putting the landscape into the genomics of trees: approaches for understanding local adaptation and population responses to changing climate. Tree Genet. Genomes 9, 901-911
82. Collalti, A. et al. (2019) The sensitivity of the forest carbon budget shifts across processes along with stand development and climate change. Ecol. Appl. 29, e01837

83. Prentice, I.C. et al. (2015) Reliable, robust and realistic: the three R's of next-generation landsurface modelling. Atmospheric Chem. Phys. 15, $5987-6005$

84. Wang, H. et al. (2017) Towards a universal model for carbon dioxide uptake by plants. Nat. Plants 3, 734-741

85. McMurtrie, R.E. and Dewar, R.C. (2011) Leaf-trait variation explained by the hypothesis that plants maximize their canopy carbon export over the lifespan of leaves. Tree Physiol. 31, 1007-1023

86. Reich, P.B. et al. (1997) From tropics to tundra: global convergence in plant functioning. Proc. Natl. Acad. Sci. U. S. A. 94, 13730-13734

87. Pavlick, R. et al. (2013) The Jena Diversity-Dynamic Global Vegetation Model (JeDi-DGVM): a diverse approach to representing terrestrial biogeography and biogeochemistry based on plant functional trade-offs. Biogeosciences 10, 4137-4177

88. Epstein, H.E. et al. (2000) A transient, nutrient-based model of Arctic plant community response to climatic warming. Ecol. Appl. 10, 824-841

89. Peters, D.P.C. (2002) Plant species dominance at a grassland-shrubland ecotone: an individual-based gap dynamics model of herbaceous and woody species. Ecol. Model. 152, 5-32

90. Wang, Y.P. et al. (2012) Correlations among leaf traits provide a significant constraint on the estimate of global gross primary production. Geophys. Res. Lett. 39, L19405

91. Kramer, K. et al. (2008) Bridging the gap between ecophysiological and genetic knowledge to assess the adaptive potential of European beech. Ecol. Model. 216, 333-353

92. Cernusak, L.A. et al. (2011) Photosynthetic physiology of eucalypts along a sub-continental rainfall gradient in northern Australia. Agric. For. Meteorol. 151, 1462-1470

93. Ishikawa, K. et al. (2007) Intraspecific variation in temperature dependence of gas exchange characteristics among Plantago asiatica ecotypes from different temperature regimes. New Phytol. $176,356-364$

94. Grassi, G. and Bagnaresi, U. (2001) Foliar morphological and physiological plasticity in Picea abies and Abies alba saplings along a natural light gradient. Tree Physiol. 21, 959-967

95. Bloomfield, K.J. et al. (2018) A continental-scale assessment of variability in leaf traits: within species, across sites and between seasons. Funct. Ecol. 32, 1492-1506

96. Kattge, J. and Knorr, W. (2007) Temperature acclimation in a biochemical model of photosynthesis: a reanalysis of data from 36 species. Plant Cell Environ. 30, 1176-1190

97. Kattge, J. et al. (2009) Quantifying photosynthetic capacity and its relationship to leaf nitrogen content for global-scale terrestrial biosphere models. Glob. Change Biol. 15, 976-991

98. Walker, A.P. et al. (2014) The relationship of leaf photosynthetic traits - Vcmax and Jmax - to leaf nitrogen, leaf phosphorus, and specific leaf area: a meta-analysis and modeling study. Ecol. Evol. 4, 3218-3235

99. Domingues, T.F. et al. (2010) Co-limitation of photosynthetic capacity by nitrogen and phosphorus in West Africa woodlands. Plant Cell Environ. 33, 959-980

100. Schulze, E.-D. et al. (1998) Carbon and nitrogen isotope discrimination and nitrogen nutrition of 
trees along a rainfall gradient in northern Australia. Funct. Plant Biol. 25, 413-425

101. Ackerly, D.D. and Cornwell, W.K. (2007) A traitbased approach to community assembly: partitioning of species trait values into within- and among-community components. Ecol. Lett. 10, 135-145

102. Körner, C. et al. (1986) Altitudinal variation in stomatal conductance, nitrogen content and leaf anatomy in different plant life forms in New Zealand. Oecologia 69, 577-588

103. Lusk, C.H. and Reich, P.B. (2000) Relationships of leaf dark respiration with light environment and tissue nitrogen content in juveniles of 11 coldtemperate tree species. Oecologia 123, 318-329

104. Hajek, P. et al. (2016) Intraspecific variation in wood anatomical, hydraulic, and foliar traits in ten European beech provenances differing in growth yield. Front. Plant Sci. 7, 791

105. Alía, R. et al. (2014) Environment-dependent microevolution in a Mediterranean pine (Pinus pinaster Aiton). BMC Evol. Biol. 14, 200

106. Ramírez-Valiente, J.A. et al. (2014) Exploring the impact of neutral evolution on intrapopulation genetic differentiation in functional traits in a longlived plant. Tree Genet. Genomes 10, 1181-1190

107. Oleksyn, J. et al. (1998) Growth and physiology of Picea abies populations from elevational transects: common garden evidence for altitudinal ecotypes and cold adaptation. Funct. Ecol. 12, 573-590

108. Wright, I.J. et al. (2005) Assessing the generality of global leaf trait relationships. New Phytol. 166 485-496

109. Niinemets, Ü. (2001) Global-scale climatic controls of leaf dry mass per area, density, and thickness in trees and shrubs. Ecology 82, 453-469

110. Weng, E. et al. (2017) Predicting vegetation type through physiological and environmental interactions with leaf traits: evergreen and deciduous forests in an earth system modeling framework. Glob. Change Biol. 23, 2482-2498

111. Brousseau, L. et al. (2013) Highly local environmental variability promotes intrapopulation divergence of quantitative traits: an example from tropical rain forest trees. Ann. Bot. 112, 1169-1179

112. Meng, T.-T. et al. (2015) Responses of leaf traits to climatic gradients: adaptive variation versus compositional shifts. Biogeosciences 12, 5339-5352

113. Fyllas, N.M. et al. (2014) Analysing Amazonian forest productivity using a new individual and trait-based model (TFS v.1). Geosci Model Dev. 7, 1251-1269

114. Körner, C. et al. (1983) Altitudinal variation of leaf diffusive conductance and leaf anatomy in heliophytes of montane New Guinea and their interrelation with microclimate. Flora 174, 91-135

115. Brendel, O. et al. (2008) Quantitative trait loci controlling water use efficiency and related traits in Quercus robur L. Tree Genet. Genomes 4, 263-278

116. Abrams, M.D. and Mostoller, S.A. (1995) Gas exchange, leaf structure and nitrogen in contrasting successional tree species growing in open and understory sites during a drought. Tree Physiol. 15, 361-370

117. Geange, S.R. et al. (2017) Phenotypic plasticity and water availability: responses of alpine herb species along an elevation gradient. Clim. Change Responses 4, 5

118. Maire, V. et al. (2015) Global effects of soil and climate on leaf photosynthetic traits and rates. Glob. Ecol. Biogeogr. 24, 706-717

119. Atkin, O.K. and Tjoelker, M.G. (2003) Thermal acclimation and the dynamic response of plant respiration to temperature. Trends Plant Sci. 8, 343-351
120. Atkin, O.K. et al. (2006) High thermal acclimation potential of both photosynthesis and respiration in two lowland Plantago species in contrast to an alpine congeneric. Glob. Change Biol. 12, 500-515

121. Bosc, A. et al. (2003) Variability of stem and branch maintenance respiration in a Pinus pinaster tree. Tree Physiol. 23, 227-236

122. Gonzalez-Meler, M.A. et al. (2004) Plant respiration and elevated atmospheric $\mathrm{CO} 2$ concentration: cellular responses and global significance. Ann. Bot. 94, 647-656

123. Gomez-Casanovas, N. et al. (2007) Changes in respiratory mitochondrial machinery and cytochrome and alternative pathway activities in response to energy demand underlie the acclimation of respiration to elevated $\mathrm{CO} 2$ in the invasive Opuntia ficus-indica. Plant Physiol. 145, 49-61

124. Atkin, O.K. et al. (2015) Global variability in leaf respiration in relation to climate, plant functional types and leaf traits. New Phytol. 206, 614-636

125. Chave, J. et al. (2009) Towards a worldwide wood economics spectrum. Ecol. Lett. 12, 351-366

126. Schuldt, B. et al. (2016) How adaptable is the hydraulic system of European beech in the face of climate change-related precipitation reduction? New Phytol. 210, 443-458

127. Dalla-Salda, G. et al. (2011) Genetic variation of xylem hydraulic properties shows that wood density is involved in adaptation to drought in Douglas-fir (Pseudotsuga menziesii (Mirb.)). Ann. For. Sci. 68, 747-757

128. Martínez-Vilalta, J. et al. (2009) Hydraulic adjustment of Scots pine across Europe. New Phytol. 184, 353-364

129. Skomarkova, M.V. et al. (2006) Inter-annual and seasonal variability of radial growth, wood density and carbon isotope ratios in tree rings of beech (Fagus sylvatica) growing in Germany and Italy. Trees 20, 571-586

130. Anderegg, W.R.L. (2015) Spatial and temporal variation in plant hydraulic traits and their relevance for climate change impacts on vegetation. New Phytol. 205, 1008-1014

131. Poyatos, R. et al. (2007) Plasticity in hydraulic architecture of Scots pine across Eurasia. Oecologia 153, 245-259

132. Maherali, H. et al. (2002) Hydraulic differentiation of Ponderosa pine populations along a climate gradient is not associated with ecotypic divergence. Funct. Ecol. 16, 510-521

133. Fonti, P. et al. (2013) Wood anatomical responses of oak saplings exposed to air warming and soil drought. Plant Biol. 15, 210-219

134. Fonti, P. and Jansen, S. (2012) Xylem plasticity in response to climate. New Phytol. 195, 734-736

135. Fonti, P. et al. (2010) Studying global change through investigation of the plastic responses of xylem anatomy in tree rings. New Phytol. 185 42-53

136. He, P. et al. (2019) Growing season temperature and precipitation are independent drivers of global variation in xylem hydraulic conductivity. Glob. Change Biol. Published online November 20, 2019. https://doi.org/10.1111/gcb.14929

137. Mencuccini, M. et al. (2019) Leaf economics and plant hydraulics drive leaf: wood area ratios. New Phytol. 224, 1544-1556

138. Hernández-Serrano, A. et al. (2013) Fire structures pine serotiny at different scales. Am. J. Bot. 100, 2349-2356

139. O'Reilly-Wapstra, J.M. et al. (2013) Chemical variation in a dominant tree species: population 


\section{Trends in Ecology \& Evolution}

divergence, selection and genetic stability across environments. PLOS ONE 8, e58416

140. Herrera, C.M. and Bazaga, P. (2013) Epigenetic correlates of plant phenotypic plasticity: DNA methylation differs between prickly and nonprickly leaves in heterophyllous Ilex aquifolium (Aquifoliaceae) trees. Bot. J. Linn. Soc. 171, $441-452$

141. Parent, G.J. et al. (2017) Insect herbivory (Choristoneura fumiferana, Tortricidea) underlies tree population structure (Picea glauca, Pinaceae). Sci. Rep. 7, 42273

142. Callis-Duehl, K. et al. (2017) Community-level relaxation of plant defenses against herbivores at high elevation. Plant Ecol. 218, 291-304

143. Fine, P.V.A. et al. (2006) The growth-defense tradeoff and habitat specialization by plants in Amazonian forests. Ecology 87, S150-S162

144. Rosell, J.A. (2016) Bark thickness across the angiosperms: more than just fire. New Phytol. 211 90-102

145. Martín-Sanz, R.C. et al. (2019) How does water availability affect the allocation to bark in a Mediterranean conifer? Front. Plant Sci. 10, 607

146. Kohnle, U. et al. (2012) Effects of seed source origin on bark thickness of Douglas-fir (Pseudotsuga menziesii) growing in southwestern Germany. Can. J. For. Res. 42, 382-399

147. Paine, C.E.T. et al. (2010) Functional explanations for variation in bark thickness in tropical rain forest trees. Funct. Ecol. 24, 1202-1210

148. Pausas, J.G. (2015) Bark thickness and fire regime. Funct. Ecol. 29, 315-327

149. Kelley, D.I. et al. (2014) Improved simulation of firevegetation interactions in the Land surface Processes and eXchanges dynamic global vegetation model (LPX-Mv1). Geosci. Model Dev. 7, 2411-2433

150. Wesołowski, T. and Rowiński, P. (2006) Timing of bud burst and tree-leaf development in a multispecies temperate forest. For. Ecol. Manag. 237, 387-393

151. Kramer, K. et al. (2017) Chilling and forcing requirements for foliage bud burst of European beech (Fagus sylvatica L.) differ between provenances and are phenotypically plastic. Agric. For. Meteorol. 234-235, 172-181

152. Howe, G.T. et al. (2003) From genotype to phenotype: unraveling the complexities of cold adaptation in forest trees. Can. J. Bot. 81, 12471266

153. Scotti-Saintagne, C. et al. (2004) Detection of quantitative trait loci controlling bud burst and height growth in Quercus robur L. Theor. Appl. Genet. 109, 1648-1659

154. Niinemets, Ü. and Tamm, Ü. (2005) Species differences in timing of leaf fall and foliage chemistry modify nutrient resorption efficiency in deciduous temperate forest stands. Tree Physiol. 25, 1001-1014

155. Doi, H. and Takahashi, M. (2008) Latitudinal patterns in the phenological responses of leaf colouring and leaf fall to climate change in Japan. Glob. Ecol. Biogeogr. 17, 556-561

156. Leinonen, I. et al. (1995) A second-order dynamic model for the frost hardiness of trees. Ann. Bot. 76, 89-95

157. Hänninen, H. and Kramer, K. (2007) A framework for modelling the annual cycle of trees in boreal and temperate regions. Silva Fenn 41 167-205

158. King, D.A. (1996) Allometry and life history of tropical trees. J. Trop. Ecol. 12, 25-44

159. King, D.A. (1997) Branch growth and biomass allocation in Abies amabilis saplings in contrasting light environments. Tree Physiol. 17, 251-258

160. Moles, A.T. et al. (2005) A brief history of seed size. Science 307, 576-580

161. de Souza, R.P. and Válio, I.F.M. (2001) Seed size seed germination, and seedling survival of Brazilian tropical tree species differing in successional status. Biotropica 33, 447-457

162. Galetti, M. et al. (2013) Functional extinction of birds drives rapid evolutionary changes in seed size. Science 340, 1086-1090

163. Wang, B. and Ives, A.R. (2016) Tree-to-tree variation in seed size and its consequences for seed dispersal versus predation by rodents. Oecologia 183, 751-762

164. Boulangeat, I. et al. (2012) Improving plant functional groups for dynamic models of biodiversity: at the crossroads between functional and community ecology. Glob. Change Biol. 18, 3464-3475

165. Giménez-Benavides, L. et al. (2005) Seed germination of high mountain Mediterranean species: altitudinal, interpopulation and interannual variability. Ecol. Res. 20, 433-444 